\title{
Viewpoint: The range utilization concept, allocation arrays, and range management science
}

\author{
DAVID L. SCARNECCHIA
}

Author is associate professor, Department of Natural Resource Sciences, Washington State University, Pullman, Wash. 99164-6410.

\begin{abstract}
The transition of range utilization from a qualitative concept in the early years of range management to a quantitative concept in today's range management science has been problematic. This paper (1) evaluates the origins, confoundings, and interpretations of range utilization in range management science, (2) presents an explicit allocation array of variables to replace the range utilization concept, and (3) examines the role of range utilization specifically, and management science generally in the present and future message of the Society for Range Management, and in range management science.
\end{abstract}

Key Words: herbage dynamics, range science education, range use

This paper is an analysis of diverse but interrelated events and perceptions of the 50th Anniversary Meeting of the Society for Range Management at Rapid City, South Dakota, 16-21 February 1997. The convergence there of a symposium on range utilization, (see papers by Sanders (1998), Smith (1998), Laycock (1998), and Krueger (1998)), considerable anniversary-inspired soul-searching about the past, present, and future of the Society and its message, and several presentations on the future of range management education (Buckhouse 1997, Launchbaugh 1997, Malechek 1997), has motivated the analysis.

The objectives of the paper are to (1) evaluate the concept, implications, applications, and interpretations of range utilization in range management science, (2) present an explicit array of variables to replace the range utilization concept, and (3) examine the role of range utilization specifically and management science generally in the present and future message of the Society for Range Management and in range management science.

To achieve the stated objectives, the paper has both technical and philosophical aspects, which are interrelated. Because it is a viewpoint paper, some stylistic latitude is requested.

\footnotetext{
The author would like to thank Dr. Grant Harris, Dr. Edward DePuit, and an anonymous reviewer for their helpful comments on this manuscript.

Paper accepted 23 May 1998.
}

La transición del concepto de utilización del pastizal de un concepto cualitativo, en los primeros años de la ciencia de manejo de pastizales, a un concepto cuantitativo, en la ciencia actual de manejo de pastizales, ha sido problemático. Este artículo (1) evalua los origenes, confusiones e interpretaciones del concepto de utilización del pastizal en la ciencia de manejo de pastizales, (2) presenta un arreglo de asignación de variables explícito para remplazar el concepto de utilización del pastizal y (3) examina especifícamente el papel del concepto de utilización del pastizal y generalmente las habilidades de la ciencia de manejo de pastizales en el mensaje presente y futuro de la Sociedad de Manejo de Pastizales y la ciencia de manejo de pastizales.

\section{Range Utilization \\ "....voodoo economics." —George Bush}

Economy of concepts, always a specious part of the art underlying range management science, reaches high art in the concept of range utilization. In few range science concepts has the attempted transition from qualitative management to quantitative science asked more from a single concept, and yielded less satisfying results. In this transition, range utilization has been uneasily quantified as "the proportion of the current years biomass production consumed or destroyed by grazing animals" (Society for Range Management 1974, 1989; Smith 1998). The practical problems with this quantified definition of range utilization are many and compounded (See, for example, Burkhardt 1997, McKinney 1997), but the essential problems are conceptu$a l$. The false simplicity of the utilization percentage hides problems of both concept and application.

In general, the logical order of concept design and application in management science might be considered

Concept- - - - -Definition- - - - -Assessment- - - - -Interpretation.

The ordering here implies that the concept, the mental image, be developed before it can be defined and used. The second step, definition of the concept, is more than just attaching words to the image; it is a critical test of how well formulated the concept is. Having explicit objectives of design for a concept will aid in defining it. The definition of a concept designed for clear systems objectives will usually be easy, but a poorly designed concept, one poorly 
designed for systems applications, will usually defy clear definition (Scarnecchia 1995).

Once a concept is defined, whether a simple variable or complex model, a method or protocol for applying the concept is needed. A concept that is a simple variable may be directly measurable or indirectly derivable. A concept that is a more complex model should include not only specific objectives of design, but also specific objectives of application. The interpretation of the assessment of a concept serves as a check on the clarity and precision of the definition and the underlying concept itself. A concept based on vague objectives will not only be poorly designed for systems applications, but will usually defy clear interpretation.

Even with the above framework in mind, analysis of the problems with the range utilization concept as defined above (Society for Range Management 1989) is difficult largely because the problems are so numerous and so intricately interrelated that the analysis becomes convoluted. Evidently the origin of the range utilization concept is largely intuitive; most range professionals seem to be able to vaguely, i.e., qualitatively, visualize what utilization is, and many can even apply an ocularly estimated percentage to it without difficulty. Attempts to define and calculate range utilization more explicitly quickly become complicated by active herbage dynamics characteristic of most situations, inviting simplifying assumptions. Attempts to reconcile the basic definition with the usual methods of herbage sampling, e.g., sequential clipping, are inevitably frustrated as well. The utilization concept contains confounded variables of basic herbage dynamics (Fig. 1), and so can be thought of as too internally confounded (Scarnecchia 1996), and too conceptually simplistic to explicitly account for the basic variables of herbage dynamics. The concept is incompatible with the fact that grazing may induce additional new growth of herbage, and the result is that under, for example, intensive rotational grazing plans, the interpretation of the concept approaches unmanagability. Conceptually, range utilization is an inadequate attempt to make a single, static variable serve in place of an explicit array of variables describing herbage dynamics under grazing (Fig. 1).

Related conceptual/practical problems exist. Utilization is definitionally dependent on an annual growth figure which, ipso facto, cannot be determined until the end of the growing season. This temporal problem is only one of the reasons Sanders (1998) questioned the value of a utilization figure as a reasonable objective in planning. The temporal problem, the static/dynamic problem described above, and the fact that none of the traditional sampling methods to assess utilization in the field actually measure growth or disappearance, are likely sources of the contention (E.T. Bartlett, personal communication, Feb., 1997) that in trying to measure utilization, range scientists are trying to measure something that isn't there.

Other practical problems with the utilization concept summarized by various authors (e.g., Smith 1998, Holechek et al. 1998), have their origins at the conceptual level. Collectively, these conceptual and practical inadequacies show that despite its intuitive, qualitative value, and its meritorious, if inexacting, historical applications, its technical value as a quantitative variable cannot be justified either conceptually or practically.

Examining the prominence of concepts in recent textbooks can be enlightening in assessing the utility of basic concepts in a science. In a recently published revision of a major textbook on range management (Holechek et al. 1998), the discussion of range utilization takes up less than 3 pages, nearly all of which is spent describing the problems with the concept, especially with its assessment and interpretation. Its conceptual inadequacies, the painfully slow but inevitable technical development of range management science, and new generations of systems-trained range scientists should eventuate a natural end to utilization as a quantitative concept. So barring counter-productive, unnatural institutional resurrections, a replacement will be needed for applications in range management science.

\section{Allocation Arrays}

The second objective of this paper is to present an array of explicit variables to replace the range utilization concept. Specific objectives of design for this array are that it (1) serve the general objectives and applications of the utilization concept it replaces, (2) consist of variables that are definitionally explicit, technically rigorous, reasonably determinable, and directly useful in wider systems applications, and (3) be flexible in structure to allow subdivision of existing variables, or inclusion of other variables for different objectives in range management science, and (4) be heuristic in the sense of encouraging improved understanding of systems to which it is applied.

An earlier paper (Scarnecchia and Kothmann 1986) presented the general variables describing herbage growth, disappearance and accumulation in grazed systems. An elementary model (Fig. 1) based on that approach is in turn the basis for an example set of variables, here termed an allocation array, which explicitly includes those herbage variables range utilization has implicitly involved. Figure 1 suggests the equations

$$
\text { DSC }=s c_{f}-s c_{i}=g-d n g-I-d_{g}
$$

where

dsc $=$ change in standing crop $(+, 0$, or -) during the period of calculation

$\mathrm{sc}_{\mathrm{f}}=$ final standing crop $(0$ or +$)$,

$\mathrm{sc}_{\mathrm{i}}=$ initial standing crop $(0$ or +$)$,

$\mathrm{g}=$ new growth during the period of calculation $(0$ or +$)$,

$\mathrm{d}_{\mathrm{ng}}=$ disappearance during the calculating period other than by stocked animals $(0$ or +$)$,

$\mathrm{d}_{\mathrm{g}}=$ disappearance (trampling losses, etc.) due to stocked animals ( 0 or + )

$I=$ herbage intake by stocked animals $(0$ or +$)$

The 7 variables in these equations can be arranged into a $1 \times 7$ matrix with units. For example:

$\left[\begin{array}{lllllll}250 & 550 & 300 & 450 & 50 & 100 & 50\end{array}\right] \mathrm{kg} / \mathrm{ha}$ or 


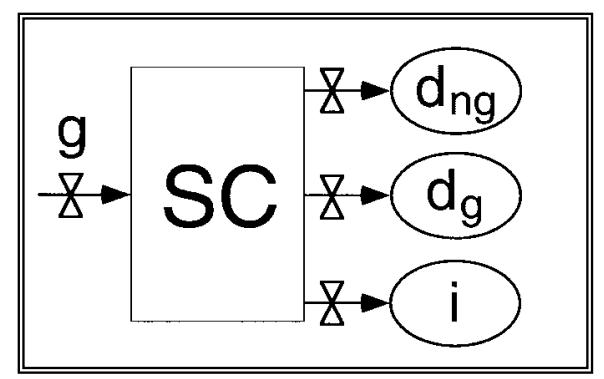

Fig. 1. Conceptual model of growth $(\mathrm{g})$, standing crop (sc), herbage disappearance not associated with grazing (dng), disappearance due to grazing but not including intake, $\left(d_{g}\right)$ and intake (I) for a grazed system.

$\left[\begin{array}{lllllll}-200 & 300 & 500 & 50 & 125 & 60 & 40\end{array}\right] \mathrm{kg} / \mathrm{ha}$.

The first example describes a period of calculation in which the standing crop increased by $250 \mathrm{~kg} / \mathrm{ha}$, from 300 $\mathrm{kg} / \mathrm{ha}$ to $550 \mathrm{~kg} / \mathrm{ha}$. The fourth entry represents the cumulative amount of new growth during the period of calculation, whether a day, a week, a grazing period, or an entire growing season. Entry 5 represents the amount of disappearance from the standing crop other than that ingested by stocked animals (I), and the amount destroyed by stocked animals $\left(\mathrm{d}_{\mathrm{g}}\right)$. Entry 6 (I) is intake of stocked animals, and entry 7 represents disappearance other than intake due to stocked animals.

In the second example matrix, total disappearance exceeds new growth, and the standing crop decreases from $500 \mathrm{~kg} / \mathrm{ha}$ to $200 \mathrm{~kg} / \mathrm{ha}$ for a change in standing crop (Dsc) of $-200 \mathrm{~kg} / \mathrm{ha}$.

Because of the additivity of the matrix entries, measurements or estimates of some variables can allow others to be calculated by addition/subtraction. A calculation of utilization, as defined by the Society for Range Management (1989) and Smith (1997) cannot be made from one of these allocation arrays, but the fraction of the initial standing crop and new growth lost to stocked animals can be calculated, and is equal to $\left(d_{g}+I\right) /\left(S C_{i}+g\right)$. Other fractions can be calculated, and they may have interpretive value for specific applications. Individual entries may be deleted from the array, aggregated or subdivided within an array, or added to the array depending on the particular variables that are relevant to the user's objectives. (For examples of other variables which might be suitable for allocation arrays, see Scarnecchia, (1994)). The specific array above is an example of the general approach.

Unlike the utilization concept, allocation arrays are easily applied and interpreted under rotational grazing, and can be used to summarize herbage dynamics both within individual grazing periods and over entire grazing seasons. In the array above, the growth and disappearance entries (4-7) are additive for individual pastures over multiple grazing periods of rotational grazing systems. These entries can be used to calculate entries 1-3 over a number of grazing cycles or on an annual basis.

Data included in allocation arrays would preferably be from relevant models of herbage dynamics and from field sampling. The need to service these arrays with data would focus attention on the basic variables of herbage dynamics, and would encourage the development of improved models of herbage dynamics and livestock intake. Data needs would also encourage improved methods of field sampling of appropriately chosen variables to provide information either directly to the arrays, or indirectly to them through identification of indicator variables to service the arrays through appropriate models of herbage dynamics. Some work has been attempted in assessing these allocation array variables (e.g., Sharrow and Motazedian 1983), but much more work will need to be done if allocation arrays are to be accurate, applied extensions of larger grazing models to aid managers in both planning and post facto assessment. Then, following Sanders' (1998) reasoning, specific entries in allocation arrays would still not necessarily be good objectives for planning, but in general, allocation arrays would, at least, be good tools.

Surely a profession that claims the kind of transcendent artistry needed to ocularly quantify a range utilization concept that cannot even be clearly conceptualized can face the modest complexity of an allocation array. In any case, before concluding that allo- cation arrays as described here are too complicated to apply and too difficult to visualize compared with a utilization concept, recognize that the apparent economies of the range utilization concept are false economies. The socalled calculation of utilization by sequential sampling of standing crop actually involves implicit assumptions about all 7 of the variables in an allocation array, but these assumptions are ignored in the reporting of the magical utilization number. Even if some of the variables in an allocation array are estimated most crudely, the result is more explicit and more informative than having these estimates lost in a utilization percentage. So a utilization percentage isn't any simplier than an allocation array; it is just less explicit, less informative, and has no clear meaning in science or art. An allocation array is a more typical example of the kind of technical foundation that often encourages refinement in science, and in most forms of art.

\section{Range Science in Education and Communication}

At the General Membership Meeting of the Society for Range Management in Rapid City, several speakers (Launchbaugh 1997, Malechek 1997, Buckhouse 1997), in different ways, examined the future of range education and communication, envisioning those skills that will be needed by range professionals in the next century. These reports emphasized many important skills that will be needed, and especially emphasized the importance of communication, of getting out our message. Regrettably, none of these speakers mentioned the need for the systems skills of management science, and their future importance in scientific and managerial communication with other disciplines for which systems skills will be a common language. More fundamentally, systems skills are critical to the future identity of range management science. The only distinct identity that range science can have beyond its more technical supporting sciences, is an integrative management science (Scarnecchia 1995). Surely our message should $=$ sound science + communication. The existence of a sympo- 
sium at the Rapid City meeting on a barely qualitative, but widely applied retro-concept like range utilization indicates that in describing herbage dynamics under grazing, our science needs at least as much work as our communication. And until we have a sound message to communicate, we might be well off incommunicado. As range management scientists and science-oriented range managers, we should reexamine our message if it includes range utilization not only as a technical objective, but as a technical tool, or in any quantitative application.

\section{Voodoo Economics}

To continue to economize by resurrecting apparently simple but internally confounded retro-concepts like range utilization, which were developed for the most qualitative applications, and attempt to make them serve as substitutes for multiple variables or models in quantitative applications, is certainly voodoo economics. Apparently, the alternative to multi-variate allocation arrays summarizing herbage dynamics is that range utilization will be periodially, endlessly, unnaturally resurrected to wander the range science landscape like a voodoo zombie from an old Bmovie. In my dictionary (Reader's Digest 1966), a zombie is "a corpse reactivated by sorcery, but still dead," and so it is, post-symposium, with utilization as an effective concept for range management science. The allocation array concept offered here is only one example of the kind of explicit, systematic tools of management science we as range professionals should be developing, refining, using, and communicating. As a technical, quantitative concept for rangeland assessment, range utilization should be buried immediately. And, based on past experiences with regrettable range science resurrections and forgettable B-movies, 6 feet probably won't be deep enough.

\section{Literature Cited}

Buckhouse, J. 1997. President's Address. Presentation at the General Membership Meeting, 50th Annual Meeting of the Society for Range Manage., Feb. 16-21, Rapid City, S. D.

Burkhardt, J.W. 1997. Grazing utilization limits: an ineffective management tool. Rangelands. 19(3):8-9.

Bush, G. Bartlett's book of quotations. Little, Brown and Co., Ltd., Boston.

Krueger, W.C. 1998. Integrating utilization measurements into monitoring programs. From: Symposium: Use, misuse of utilization and stubble height measurements. Presented at the 50th Annual Meeting of the Soc. for Range Manage., Feb. 16-21, Rapid City, S. D. (In press).

Laycock, W.A. 1998. Variation in utilization estimates caused by differences among methods, years and observers. From: Symposium: Use, misuse and meaning of utilization and stubble height measurements. Presented at the 50th Annual Meeting of the Soc. for Range Manage., Feb. 16-21, Rapid City, S.D. (In press).

Launchbaugh, K. 1997. Technical skills for tomorrow's managers. Presentation at General Membership Meeting, 50th Annual Meeting of the Soc. for Range Manage., Feb. 16-21, Rapid City, S.D.

Holechek, J.L., R.D. Pieper, and C.H. Herbel. 1998. Range management, 3rd ed. Prentice Hall, Upper Saddle River, N.J.

Malechek, J. 1997. Future for range education. Presentation at General Membership Meeting, 50th Annual Meeting of the Soc. for Range Manage., Feb. 16-21, Rapid City, S.D.

McKinney, E. 1997. It may be utilization, but is it management? Rangelands. 19(3)4-7.

Reader's Digest. 1996. The Reader's Digest Great Encyclopedic Dictionary. Reader's Digest Assoc., Pleasantville, N.Y.

Sanders, K. 1998. Utilization standards: the quandary revisited. From: Symposium: Use, misuse and meaning of utilization and stubble height measurements. Presentation at General Membership Meeting, 50th Annual Meeting of the Soc. for Range Manage., Feb. 16-21, Rapid City, S.D. (In press).
Scarnecchia, D.L. 1994. A viewpoint: Using multiple variables as indicators in grazing research and management. J. Range Manage. 47:107-111.

Scarnecchia, D.L. 1995. The rangeland condition concept and range science's search for identity: a systems viewpoint. J. Range Manage. 48:181-186.

Scarnecchia, D.L. 1996. Viewpoint: Concept design in range management science. J. Range Manage. 49:421-424.

Scarnecchia, D.L. and M.M. Kothmann. 1986. Observations on herbage growth, disappearance, and accumulation under livestock grazing. J. Range Manage. 39:86-87.

Sharrow, S.H. and I. Motazedian. 1983. A comparison of three methods for estimating forage disappearance. J. Range Manage. 36:469-471.

Smith, L. 1998. Seasonal effects on measurement and interpretation of utilization. From: Symposium: Use, misuse and meaning of utilization and stubble height measurements. Presentation at General Membership Meeting, 50th Annual Meeting of the Soc. for Range Manage., Feb. 16-21, Rapid City, S.D. (In press).

Society for Range Management. 1974. A glossary of terms used in range management. Soc. for Range Manage. Denver, Colo.

Society for Range Management. 1989. A glossary of terms used in range management. Soc. for Range Manage. Denver, Colo. 